Domínguez-Vázquez, G., S. Raygadas, J. L. León-Cortés and A. Pérez-Arteaga. 2021. Pollen analysis as an ecological proxy for the assessment of habitat use of the endangered Black-polled Yellowthroat (Geothlypis speciosa) and sympatric Common Yellowthroat (G. trichas). Avian Conservation and Ecology 16(2):2. https://doi.org/10.5751/ACE-01856-160202

Copyright (C) 2021 by the author(s). Published here under license by the Resilience Alliance.

\title{
Pollen analysis as an ecological proxy for the assessment of habitat use of the endangered Black-polled Yellowthroat (Geothlypis speciosa) and sympatric Common Yellowthroat (G. trichas)
}

\author{
Gabriela Domínguez-Vázquez ${ }^{1}$, Susana Raygadas ${ }^{1}$, Jorge L. León-Cortés ${ }^{2}$ and Alejandro Pérez-Arteaga ${ }^{1}$ \\ ${ }^{1}$ Facultad de Biología, Universidad Michoacana de San Nicolás de Hidalgo, Morelia, Mexico, ${ }^{2}$ Departamento de Conservación de \\ la Biodiversidad, El Colegio de la Frontera Sur, San Cristóbal de Las Casas, México
}

\begin{abstract}
We present a novel application of palynological analyses to assess habitat use of the endangered Black-polled Yellowthroat (Geothlypis speciosa) and the sympatric Common Yellowthroat (G. trichas) in Lake Cuitzeo, Mexico. Since field monitoring of songbirds can be difficult due to complex habitat requirements, behavioral, or logistical issues, our results provide an important methodological alternative for habitat assessment and conservation monitoring of species difficult to study with traditional methods. We found significant differences between pollen rain in water samples and pollen loads in feathers. Pollen loads were comparable between bird species during both rainy and dry seasons. Contrary to previous assumptions, Black-polled Yellowthroats showed pollen loads associated with terrestrial habitats, particularly during the dry season. Our results on equitability resource-use, showed marked differences between seasons, being more homogeneous in the dry season than in the rainy season. In addition, equitability values of pollen loads were similar between sexes in Common Yellowthroat but significantly higher in males as compared to females' Black-polled Yellowthroats, suggesting some degree of resource partitioning. GLM's identified a significantly negative relationship between anemophilous and entomophilous pollination syndromes in both species and the pollen rain recorded during dry and rainy seasons, as well as a significant effect of season sampling on pollen load, but no effect of species, sex, or any interaction with season upon pollen loads. We concluded that pollen analysis was a useful tool for the study of use of habitat in birds.
\end{abstract}

\section{Analyse du pollen comme substitut écologique de l'évaluation de l'utilisation de l'habitat par l'espèce menacée de la paruline à face noire (Geothlypis speciosa) et de la paruline masquée (G. trichas)}

RÉSUMÉ. Nous présentons une nouvelle application des analyses palynologiques pour évaluer l'utilisation de l'habitat de la paruline à face noire (Geothlypis speciosa) menacée et de la paruline masquée ( $G$. Trichas) sympatrique dans la région du lac Cuitzeo, au Mexique. Dans la mesure où la surveillance des passereaux sur le terrain peut être difficile en raison des exigences complexes de l'habitat ou de problèmes comportementaux ou logistiques, nos résultats offrent une alternative méthodologique intéressante pour l'évaluation de l'habitat et la surveillance de la conservation des espèces difficiles à étudier avec les méthodes traditionnelles. Nous avons constaté des différences significatives entre la pluie pollinique dans les échantillons d'eau et les charges polliniques dans les plumes. Les charges polliniques étaient comparables entre les espèces d'oiseaux au cours de la saison des pluies et de la saison sèche. Contrairement aux hypothèses précédentes, les parulines à face noire présentaient des charges polliniques associées à des habitats terrestres, en particulier pendant la saison sèche. Nos résultats sur l'utilisation des ressources équitables présentaient des différences marquées entre les saisons et étaient plus homogènes à la saison sèche qu'à la saison des pluies. En outre, les valeurs d'équitabilité des charges polliniques étaient similaires entre les sexes chez la paruline masquée, mais nettement supérieures chez les mâles que chez les femelles parulines à face noire, ce qui suggère un certain degré de partitionnement de ressources. Les modélisations linéaires générales ont identifié une relation nettement négative entre les syndromes de pollinisation anémophile et entomophile chez les deux espèces et la pluie pollinique enregistrée pendant la saison sèche et la saison des pluies, ainsi qu'un effet significatif de l'échantillonnage saisonnier sur la charge pollinique, mais aucun effet des espèces, du sexe ou de toute interaction avec la saison sur les charges polliniques. Nous en avons conclu que l'analyse pollinique constituait un outil utile pour l'étude de l'utilisation de l'habitat chez les oiseaux.

Key Words: conservation planning; Cuitzeo; feathers; palynology; pollen rain; vegetation; wetlands

\section{INTRODUCTION}

Traditional methods to study habitat use in songbirds rely heavily on data obtained by direct observations upon individuals; however, this is not always possible due to low abundance, reluctance to vocalize, secrete behavior, or inaccessibility, which in turn makes it difficult for researchers to obtain enough detections to estimate habitat use patterns (Bobay et al. 2018). Consequently, such studies can become impractical to implement, leading researchers to use indirect techniques such as capturerecapture, radio and satellite tracking, and camera traps. One form of indirect data gathering is the study of pollen in bird

Address of Correspondent: Alejandro Pérez-Arteaga, Edificio R, Ciudad Universitaria, Francisco J. Múgica s/n, Col. Felícitas del Río, Morelia, Michoacán 58030, Mexico., alejandro.perez@umich.mx 
feathers; however, although copious data exist for species-level relationships (e.g., polinization by hummingbirds), it has been rarely used at the habitat level (e.g., Cecere et al. 2011, Wood et al. 2014). Because of their intricate structure, feathers can hold pollen loads by trapping grains directly from physical contact with flowering plants or from pollen rain (Waateringe 1998). Pollen rain represents an array of pollen and spores produced by the local or regional vegetation, that remain in the air until falling on a particular substrate (studies commonly rely on moss pollsters but can use surface soil, bark, or surface water; Zhang et al. 2020). Pollen rain is commonly used as a surrogate of habitat features, as it reflects the structure and composition of surrounding vegetation (Domínguez-Vázquez et al. 2004). In this study, we analyzed pollen rain and pollen loads in feathers, to study habitat use components for two wetland-related warblers with contrasting conservation needs.

The wetland-obligate Black-polled Yellowthroat (Geothlypis speciosa, BPY) is one of the most vulnerable songbirds in Mexico. A rare species occurring in only six wetlands in the central highlands, it is restricted to lakeshore and river cattail (Typha: Typhaceae) and bulrush (Schoenoplectus: Cyperaceae) marshes, where desiccation and fire limit its dispersal capabilities (Escalante et al. 2009, Pérez-Arteaga et al. 2018). Because of its reduced range and restricted habitat availability, it is globally endangered (Peterson and Navarro-Sigüenza 2016, Ortiz-Pulido 2018). However, no auto-ecological assessments exist that can be translated into specific conservation strategies. Across their range, BPY members coexist with Common Yellowthroats ( $G$. trichas, $\mathrm{CY}$ ), the latter with resident and migratory populations in large lakes as Cuitzeo and Pátzcuaro (Pérez-Arteaga et al. 2018). As habitat generalists, CY in Mexico use a wide array of habitats as wetlands, temperate forests, scrublands, drainage ditches, hedgerows, and orchards (Howell and Webb 1995, Ruiz et al. 2019, Guzy and Ritchison 2020). Lake Cuitzeo is the main stronghold of BPY, holding $46 \%$ of presence records for the species and $57 \%$ of suitable habitat (Pérez-Arteaga et al. 2018). Cuitzeo is the second largest freshwater lake in Mexico, encompassing around $4,000 \mathrm{~km}^{2}$ (Sagardia 2005). Lake Cuitzeo is of great relevance for conservation of migratory and resident terrestrial and aquatic birds; although surprisingly, it is not protected under any state or federal scheme in Mexico, nor holds the Ramsar Convention recognition despite meeting qualifying criteria (Pérez-Arteaga et al. 2002).

Here, we explore palynological techniques as an ecological proxy to address two research questions for the Lake Cuitzeo BPY's population: 1) do BPY foray outside cattail and bulrush marsh habitats? And 2) do sympatric, potentially competing CY display similar habitat use patterns? We approached these issues through different angles: are there identifiable differences between pollen rain in water and pollen loads in feathers? If so, do pollen loads from feathers indicate use of non-marsh habitats by BPY? Also, do pollen loads differ between seasons, species, or sex?

\section{METHODS}

The study was carried out in Lake Cuitzeo, in the central Mexican state of Michoacán $\left(19.87^{\circ}\right.$ to $20.06^{\circ},-100.84^{\circ}$ to $-101.32^{\circ}$; altitude $1820 \mathrm{~m}$ a.s.1.). As there were no moss pollsters around the lake, we took surface water samples to analyze current pollen rain.
We sampled six sites in a mixed (cattail/bulrush) marsh in the southern portion of the lake. For every site, we collected 10 subsamples of water $(10 \mathrm{ml}$ each). We sampled in August and November that currently represents pollen rain during rainy (June-September) and dry (October-May) seasons. Additionally, we collected botanical specimens as a reference for pollen identification (stored in the Laboratory of Palynology at UMSNH). To determine pollen loads from feathers, we mistnetted BPY and CY individuals in the same general location as to water sampling sites. Using small stationery scissors, we cut one breast feather from every bird, storing each feather in a sealed paper envelope for later pollen analyses. We captured birds once every month (June-May) following applicable ethical guidelines (Fair et al. 2010), releasing birds on site.

At the lab, we homogenized water subsamples from each site. To extract the pollen from the feathers, we grinded feathers with 10 $\mathrm{ml}$ of $\mathrm{KOH}$ on a glass mortar, then centrifuged and decanted the solution. For both water and feather samples, we applied the acetolysis method, preserving pollen grains with glycerin (Erdtman 1960). A minimum of 300 pollen grains from each sample was counted with a 400X optic microscope (Carl Zeiss Axiostar Plus), classifying pollen taxa as secondary, arboreal, and aquatic, according to the main local vegetation types (CastroLópez et al 2020). We used pollen taxa with $>5 \%$ of total pollen for further analysis. To test for differences in pollen loads between seasons and species, we used Mann-Whitney $U$ exact tests. As a measure to interpret similarities in pollen loads, we estimated evenness in which pollen grains were distributed among pollen taxa and determined percentage overlap (Krebs 1999) and equitability (Pielou 1975, Achacoso et al. 2016), using Past 3.24 (Hammer et al. 2001). To explore the relation between the pollen pollination syndrome in the different species and the pollen rain during dry and rainy seasons, we used a general linear model (GLM) with normal error distribution to test for the effects of species, sex, and season on bird pollen loads. For GLM, sampling season was included as a random factor. In the model, normality of the residuals was determined with Shapiro-Wilk tests, and homogeneity of variance was examined with Levene's test of equity of error variances. We used IBM SPSS Statistics (V26, 2019) and $P=0.05$ for all statistic tests.

\section{RESULTS}

We obtained a total of 74 samples (18 water samples, 56 feather samples), of which 22 were BPY (15 males, 7 females) and $34 \mathrm{CY}$ ( 25 males, 9 females). We identified 25 pollen taxa from pollen rain and from pollen in feathers of BPY and CY (Supplementary Table A1.1).

We found significant differences $(F=6.41, P=0.014, \mathrm{df}=62)$ in pollen rain from rainy and dry seasons for secondary and arboreal pollen, being all main pollen taxa different between seasons. When comparing pollen loads between seasons, BPY showed significant differences for secondary and aquatic vegetation, while CY did so for secondary, arboreal, and aquatic vegetation. Pollen loads of BPY were significantly different between seasons for Poaceae, Onagraceae, Peperomia, and Typha; in CY, pollen loads differed significantly between seasons for Poaceae, Onagraceae, and Peperomia. Detailed inter-season comparisons are shown in Supplementary Table A1.2. 
Intra-season comparisons showed significant differences $(\mathrm{P}<$ 0.05 ) between pollen rain and pollen loads in BPY and CY in both seasons, particularly when considering vegetation types (Supplementary Fig. A1.1). Pollen rain was different from pollen loads for Onagraceae and Peperomia in the rainy season, and for Poaceae, Peperomia, and Typha in the dry season; pollen loads in BPY were comparable to CY in both seasons. Complete intraseason comparisons are shown in Supplementary Table A1.3.

Pollen loads showed large ( $>69 \%$ ) overlap during both rainy and dry seasons (Fig. 1). Equitability (Supplementary Fig. A1.2.) was lower in the rainy season, showing less uniform pollen loads for both species, of which Poaceae was more abundant for both bird species (Fig. 1A). In the dry season, equitability was higher, with a more even representation of seven main taxa (Figs. 1B). Equitability $( \pm 95 \% \mathrm{CI})$ for the entire study period was not significantly different $(\mathrm{P}=0.2123)$ between $\mathrm{BPY}$ and $\mathrm{CY}$. Equitability of pollen loads was larger $(\mathrm{P}=0.0001)$ in males BPY $(0.74 \pm 0.03)$ than females $(0.64 \pm 0.06)$; in $\mathrm{CY}$, values were marginally similar $(\mathrm{P}=0.0417)$ in males $(0.71 \pm 0.02)$ and females $(0.68 \pm 0.05)$. Both species showed larger $(P=0.0001)$ equitability in the dry season than the rainy season. GLM confirmed that the pollen rain composition was dominated by anemophilous pollen that were trapped passively in the lake, while birds use the different habitats present in the lake as the resource is available (Fig. 2). We detected a significant effect of season sampling on pollen load $\left(F_{1,63}=7.694, P=0.007\right)$, but there was no significant effect of species, sex, or any interaction with season upon pollen bird loads.

Fig. 1. Pollen loads (mean \pm SE) of main taxa from Blackpolled Yellowthroat (Geothlypis speciosa) and Common Yellowthroat (G. trichas). (A), rainy season; (B), dry season.
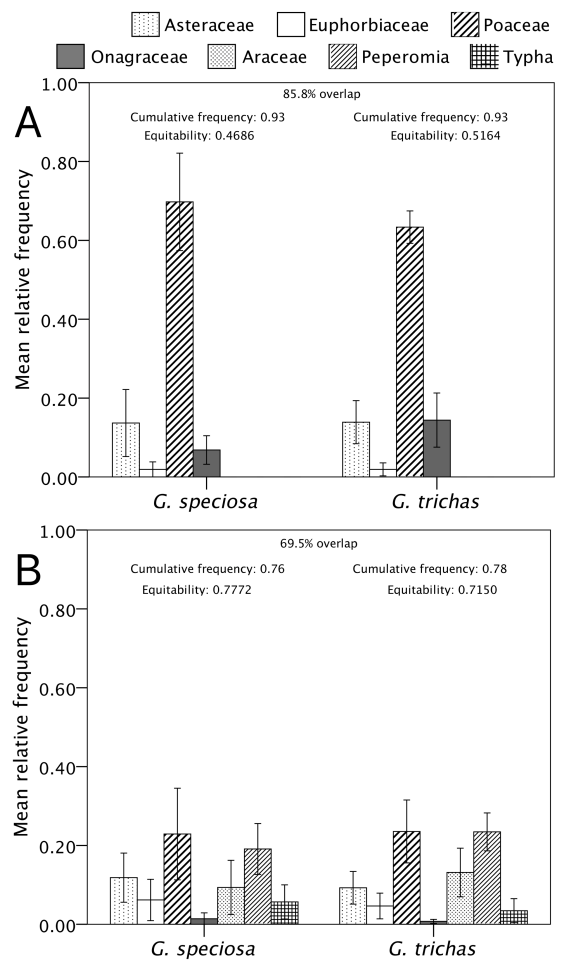

Fig. 2. Resource partition in Lake Cuitzeo, Mexico, for Blackpolled Yellowthroat (Geothlypis speciosa) and Common Yellowthroat ( $G$. trichas). Values of $\mathrm{X}$ and $\mathrm{Y}$ axis represent pollen counts.

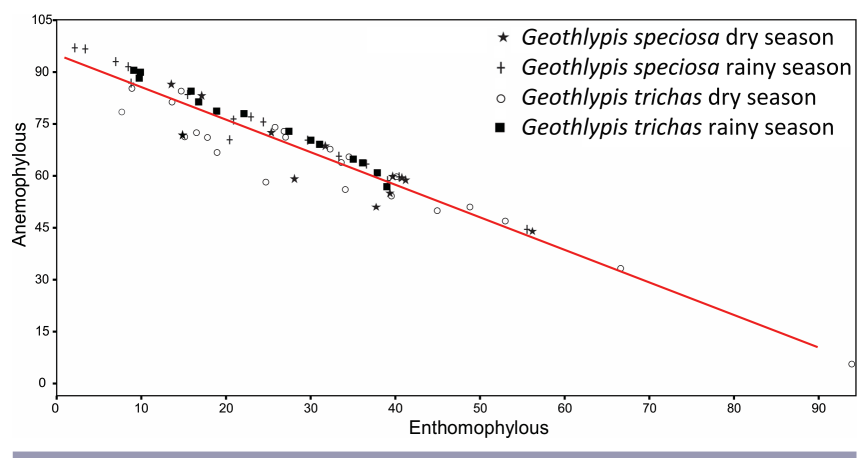

\section{DISCUSSION}

Palynological techniques provide a novel approach for acquiring habitat use data for birds that are difficult to monitor through traditional field methods, as is the case for our study species. Our results showed that feathers effectively trapped pollen grains, its composition being different from pollen rain samples, and likely reflecting a mechanism of direct and active pollen capture in feathers rather than merely passively trapping pollen rain from their environment. BPY and CY had similar pollen loads, in line with the assumption that closely related, coexisting species usually show comparable foraging habits and broadly overlapping diets if resources are relatively abundant (Rosenberg et al. 1982, Bregman et al. 2015, Trevelline et al. 2018). We found no evidence of resource partitioning between sexes of $\mathrm{CY}$ as reported elsewhere (Ornat and Greenberg 1990, Morimoto and Wasserman 1991), but differences in equitability values and variation in pollen loads suggest resource partitioning in BPY. Possible explanations are that females occupy fewer plant species, thus exhibiting more specific habitat requirements, or move shorter distances than males; however, further data are needed to clarify intra-specific variations in pollen loads.

Previous information indicates that BPY is a highly specialized water-dependent warbler that uses cattail-bulrush habitats exclusively (Escalante et al. 2009, BirdLife International 2016). However, our results showed unsuspected habitat use information, indicating use of additional habitats. While the presence of pollen in feathers from distant areas can never be fully ruled out, we consider that observed pollen loads actually reflect the immediate surrounding marsh vegetation of Lake Cuitzeo. Previous assessments on BPYs' distribution range suggest that more than half (ca. $60 \%$ ) of the estimated suitable habitat for the species is found at Lake Cuitzeo (Pérez-Arteaga et al. 2018). Furthermore, our previous observations suggest that at Lake Cuitzeo, BPY accurately find resources in relatively narrow areas with limited movement in and out, and hence we do not expect that potential habitat from remote populations (perhaps 40-50 $\mathrm{km}$ away from our study site) would have had a large effect on the observed pollen loads. 
Marked differences in pollen loads between seasons, shown by equitability resource-use, suggest that food resources (insects) can be more evenly distributed across a wider area or plant substrates during the dry season, potentially increasing bird visitation to different habitats (see Sandoval et al. 2019), likely to secondary vegetation. Pollen from plants in secondary vegetation are generally heavier, relying on insect dispersal, which in turn suggests necessary bird movements outside or near the edges of the lake where such vegetation is present (Rojas-Moreno and Novelo-Retana 1995). Allochthonous arboreal pollen is generally wind-dispersed, so its presence on birds is not necessarily an indication of wooded habitats. Another example is the use of floating vegetation, as shown by Araceae pollen in BPY and CY. Family Araceae is represented in the lake only by the invasive freefloating water lettuce (Pistia stroites), forming large mats where water has retreated, holding a large abundance of insects (Castillo and Huamantinco 2020). Araceae pollen is insect dispersed (Jaklič 2020), which indicates direct feather contact with the plant. At Lake Cuitzeo, temporal variation of pollen loads indicated a significant decreasing change in feather pollen-type load, i.e., from anemophylous to entomophylous. In this regard, our results are in line with previous evidence that showed insectivorous/ frugivorous birds tracking temporal changes in resources at local scales (Levey 1988; García and Ortiz-Pulido 2004, Blendinger et al. 2012) are likely influenced by resource fluctuations in adjacent habitats. During the dry season, abundant anemophylous-type pollen attaches to feathers of birds searching for resources through marsh vegetation; during the wet season, insect populations are very abundant, becoming the main food resource for birds and pollen rain decreases, but still attaches to birds' feathers.

In conclusion, although it was believed BPY used wetlands exclusively, they also use terrestrial habitats, and its habitat use is markedly different between rainy and dry seasons, likely due to temporal differences in the distribution of food resources. Given that our pollen analysis reflects habitat use patterns and flags specific resource use, this will help fill the ecological knowledge gap about species like Black-polled Yellowthroat, and definitively open a feasible alternative for the study of restricted-range species in discrete habitats. We believe that palynological analysis applied to ecological bird research represents novel techniques easy to use and affordable, avoiding some logistical problems associated with more traditionally intensive field methods.

\section{Responses to this article can be read online at:} https://www.ace-eco.org/issues/responses.php/1856

\section{Acknowledgments:}

This research was partly funded by the Universidad Michoacana de San Nicolás de Hidalgo (G. Domínguez- Vázquez, CIC/10/11, CIC/2021; A. Pérez-Arteaga, CIC/2021), which also provided facilities and equipment. During the study, S. Raygadas was supported by a M.Sc. scholarship from Mexico's Council of Science and Technology (CONACYT). J. L. León-Cortés was supported by CONACYT grant 258792:CB-2015-01. Capture permits were provided by Mexico's Secretariat of Environment and Natural Resources (SGPA/DGVS/00955/08).

\section{LITERATURE CITED}

Achacoso, S. C., A. M. P. Walag, and L. L. Saab. 2016. A rapid assessment of foliage spider fauna diversity in Sinaloc, El Salvador City, Philippines: a comparison between habitats receiving different degrees of disturbance. Biodiversity 17:156-161. https://doi.org/10.1080/14888386.2016.1258331

BirdLife International. 2016. The IUCN Red List of Threatened Species 2016: Geothlypis speciosa. BirdLife International, Cambridge, UK. http://dx.doi.org/10.2305

Blendinger, P. G., R. A. Ruggera, M. G. N. Montellano, L. Macchi, L., P. V. Zelaya, M. E. Álvarez, E. Martin, O. Osinaga, R. Sánchez, and J. Haedo. 2012. Fine-tuning the fruit-tracking hypothesis: spatiotemporal links between fruit availability and fruit consumption by birds in Andean mountain forests. Journal of Animal Ecology 81:1298-1310. https://doi.org/10.1111/ j.1365-2656.2012.02011.X

Bobay, L. R., P. J. Taillie, and C. E. Moorman. 2018. Use of autonomous recording units increased detection of a secretive marsh bird. Journal of Field Ornithology 89:384-392. https://doi. org/10.1111/jofo.12274

Bregman, T. P., A. C. Lees, N. Seddon, H. E. MacGregor, B. Darski, A. Aleixo, M. Bonsall, and J. A. Tobias. 2015. Species interactions regulate the collapse of biodiversity and ecosystem function in tropical forest fragments. Ecology 96:2692-2704. https://doi.org/10.1890/14-1731.1

Castillo, R. M., and A. A. Huamantinco. 2020. Spatial variation of the aquatic macroinvertebrates community in the littoral zone of the Santa Rosa coastal wetland, Lima, Peru. Revista de Biología Tropical 68:50-68. https://doi.org/10.15517/RBT. V68I1.35233

Castro-López, V., G. Domínguez-Vázquez, G. A. Islebe, A. G. Priego-Santander, and A. Velázquez. 2020. Modern pollenvegetation relationships across a landscape mosaic in central México. Review of Paleobotany and Palynology 104362. https:// doi.org/10.1016/j.revpalbo.2020.104362

Cecere, J. G., L. Cornara, S. Mezzetta, A. Ferri, F. Spina, and L. Boitani. 2011. Pollen couriers across the Mediterranean: the case of migrating warblers. Ardea 99:33-42. https://doi.

org/10.5253/078.099.0105

Domínguez-Vázquez, G., G. A. Islebe, and R. VillanuevaGutiérrez. 2004. Modern pollen deposition in Lacandon forest, Chiapas, Mexico. Review of Paleobotany and Palynology 302. 131:105-116. https://doi.org/10.1016/j.revpalbo.2004.03.004

Erdtman, G. 1960. The acetolysis method. Svensk Botanisk Tidskrift 54:561-564.

Escalante, P., L. Márquez-Valdelamar, P. De La Torre, J. P. Laclette, and J. Klicka. 2009. Evolutionary history of a prominent North American warbler clade: The Oporornis-Geothlypis complex. Molecular Phylogenetics and Evolution 53:668-678. https://doi.org/10.1016/j.ympev.2009.07.014

Fair, J., E. Paul, and J. Jones. 2010. Guidelines to the use of wild birds in research. Ornithological Council, Washington, D.C., USA. 
García, D., and R. Ortiz-Pulido. 2004. Patterns of resource tracking by avian frugivores at multiple spatial scales: two case studies on discordance among scales. Ecography 27:187-196. https://doi.org/10.1111/j.0906-7590.2004.03751.x

Guzy, M. J., and G. Ritchison. 2020. Common Yellowthroat (Geothlypis trichas), version 1.0. In P. G. Rodewald, editor. Birds of the World. Cornell Lab of Ornithology, Ithaca, New York, USA. https://doi.org/10.2173/bow.comyel.01

Hammer, Ø., D. A. T. Harper, and P. D. Ryan. 2001. PAST: Paleontological statistics software package for education and data analysis. Palaeontologia Electronica 4:1-9.

Howell, S. N. G., and S. Webb. 1995. A guide to the birds of Mexico and northern Central America. Oxford University Press, New York, New York, USA.

Jaklič, M., Š. Koren, and N. Jogan. 2020. Alien water lettuce (Pistia stratiotes L.) outcompeted native macrophytes and altered the ecological conditions of a sava oxbow lake (SE Slovenia). Acta Botanica Croatica 79:35-42. https://doi.org/10.37427/botcro-2020-009

Krebs, C. J. 1999. Ecological methodology, 2nd edition. Benjamin/Cummings, Menlo Park, California, USA.

Levey, D. J. 1988. Spatial and temporal variation in Costa Rican fruit and fruit-eating bird abundance. Ecological Monographs 58:251-269. https://doi.org/10.2307/1942539

Morimoto, D. C., and F. E. Wasserman. 1991. Intersexual and interspecific differences in the foraging behavior of Rufous-sided Towhees, Common Yellowthroats and Prairie Warblers in the Pine Barrens of southeastern Massachusetts. Journal of Field Ornithology 62:436-449.

Ornat, A. L., and R. Greenberg. 1990. Sexual segregation by habitat in migratory warblers in Quintana Roo, Mexico. The Auk 107:539-543. https://doi.org/10.1093/auk/107.3.539

Ortiz-Pulido, R. 2018. Which bird species are endangered in Mexico? Huitzil 19:237-272. http://dx.doi.org/10.28947/ hrmo.2018.19.2.348.

Pérez-Arteaga, A., K. J. Gaston, and M. Kershaw. 2002. Undesignated sites in Mexico qualifying as wetlands of international importance. Biological Conservation 107:47-57. https://doi.org/10.1016/S0006-3207(02)00043-5

Pérez-Arteaga, A., T. Monterrubio-Rico, O. Delgado-Carrillo, R. Cancino-Murillo, and J. Salgado-Ortiz. 2018. Updating the distribution range of the endangered Black-polled Yellowthroat (Geothlypis speciosa). Ornitología Neotropical 29:51-57.

Peterson, A. T., and A. G. Navarro-Sigüenza. 2016. Bird conservation and biodiversity research in Mexico: status and priorities. Journal of Field Ornithology 87:121-132. https://doi. org/10.1111/jofo. 12146
Pielou, E. C. 1975. Ecological Diversity, Vol. 8. John Wiley \& Sons, New York, New York, USA.

Rojas-Moreno, J., and A. Novelo-Retana. 1995. Flora y vegetación acuáticas del Lago de Cuitzeo, Michoacán, México. Acta Botánica Mexicana 31:1-17.

Rosenberg, K. V., R. D. Ohmart, and B. W. Anderson. 1982. Community organization of riparian breeding birds: response to an annual resource peak. The Auk 99:260-274. https://doi. org/10.1093/auk/99.2.260

Ruiz, M. D., J. L. León-Cortés, P. L. Enríquez, C. García-Estrada, and J. L. R. Salazar. 2019. Habitat-use patterns among migrant and resident landbirds of contrasting dietary habits in a southern Mexican wetland. Ardeola 66:291-310. https://doi.org/10.13157/ arla.66.2.2019.ra3

Sagardia, R. 2005. Use of subpixel classifier for wetland mapping: a case study of the Cuitzeo Lake, Mexico. M.Sc. Thesis, International Institute for Geo-information Science and Earth Observation, Enschede, The Netherlands.

Sandoval, L., C. O. Morales, J. D. Ramírez-Fernández, P. Hanson, L. R. Murillo-Hiller, and G. Barrantes. 2019. The forgotten habitats in conservation: early successional vegetation. Revista de Biología Tropical 67: S36-S52. https://doi.org/10.15517/RBT. V67I2SUPL.37202

Trevelline, B. K., T. Nuttle, B. D. Hoenig, N. L. Brouwer, B. A. Porter, and S. C. Latta. 2018. DNA metabarcoding of nestling feces reveals provisioning of aquatic prey and resource partitioning among Neotropical migratory songbirds in a riparian habitat. Oecologia 187:85-98. https://doi.org/10.1007/ s00442-018-4136-0

Waateringe, W. G.-V. 1998. Pollen in animal coats and bird feathers. Review of Palaeobotany and Palynology 103:11-16. https://doi.org/10.1016/S0034-6667(98)00021-9

Wood, M. J., P. J. Morgan, J. C. Webb, A. E. Goodenough, F. M. Chambers, and A. G. Hart. 2014. Exploring the prevalence and diversity of pollen carried by four species of migratory Old World warbler (Sylvioidea) on arrival in the UK. Bird Study 61:361-370. https://doi.org/10.1080/00063657.2014.938017

Zhang, Z. Y., F. C. Yang, D. M. Cheng, D. K. Ferguson, W. Hu, Y. Z. Li, and C. S. Li. 2020. Comparison between two kinds of natural pollen traps in tropical China: ants' nests on tree branches versus surface soil. Palynology 44:4-11. https://doi. org/10.1080/01916122.2018.1549117
Editor-in-Chief: Keith A.Hobson Subject Editor: Sergio A.Cabrera Cruz

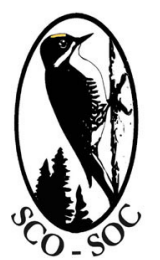

Sponsored by the Society of Canadian Ornithologists and Birds Canada

Parrainée par la Société des ornithologistes du Canada et Oiseaux Canada 


\section{Appendix 1.}

Composition and Comparisons of Pollen Rain and Pollen Loads of Black-polled Yellowthroat (Geothlypis speciosa) and Common Yellowthroat (G. trichas) from Lake Cuitzeo, Mexico.

Table A1.1. Relative frequency (mean $\pm S E$ ) of pollen taxa in pollen rain and pollen loads in Blackpolled Yellowthroat (BPY) and Common Yellowthroat (CY) from Lake Cuitzeo, Mexico, pooled for the study period.

\begin{tabular}{|c|c|c|c|}
\hline & Pollen rain $(N=18)$ & $\mathrm{BPY}(N=22)$ & $\mathrm{CY}(N=34)$ \\
\hline \multicolumn{4}{|l|}{ Secondary: } \\
\hline Cistaceae & 0 & $0.0218 \pm 0.0121$ & $0.0157 \pm 0.0109$ \\
\hline Asteraceae & $0.1129 \pm 0.0185$ & $0.1251 \pm 0.0246$ & $0.1023 \pm 0.0175$ \\
\hline Convolvulaceae & 0 & $0.0023 \pm 0.0014$ & $0.0029 \pm 0.0014$ \\
\hline Euphorbiaceae & $0.0034 \pm 0.0021$ & $0.0463 \pm 0.0174$ & $0.0409 \pm 0.0131$ \\
\hline Poaceae & $0.6160 \pm 0.0297$ & $0.3995 \pm 0.0649$ & $0.3175 \pm 0.0424$ \\
\hline Solanaceae & $0.0030 \pm 0.0019$ & $0.0158 \pm 0.0047$ & $0.0072 \pm 0.0029$ \\
\hline Lamiaceae & 0 & $0.0082 \pm 0.0037$ & $0.0075 \pm 0.0026$ \\
\hline Nyctaginaceae & 0 & 0 & $0.0042 \pm 0.0038$ \\
\hline Onagraceae & 0 & $0.0339 \pm 0.0097$ & $0.0357 \pm 0.0119$ \\
\hline \multicolumn{4}{|l|}{ Arboreal: } \\
\hline Anacardiaceae & $0.0036 \pm 0.0028$ & $0.0128 \pm 0.0067$ & $0.0072 \pm 0.0026$ \\
\hline Fabaceae & $0.0899 \pm 0.0172$ & $0.0276 \pm 0.0077$ & $0.0292 \pm 0.0080$ \\
\hline Malghipiaceae & 0 & $0.0026 \pm 0.0026$ & $0.0052 \pm 0.0052$ \\
\hline Mimosoideae & $0.0121 \pm 0.0034$ & $0.0118 \pm 0.0118$ & $0.0009 \pm 0.0006$ \\
\hline Myricaceae & 0 & $0.0027 \pm 0.0022$ & $0.0030 \pm 0.0019$ \\
\hline Myrthaceae & $0.0048 \pm 0.0027$ & $0.0157 \pm 0.0064$ & $0.0081 \pm 0.0036$ \\
\hline Sapotaceae & $0.0009 \pm 0.0009$ & $0.0006 \pm 0.0006$ & $0.0108 \pm 0.0101$ \\
\hline Urticaceae & $0.0039 \pm 0.0023$ & 0 & 0 \\
\hline Boraginaceae & $0.0011 \pm 0.0006$ & $0.0102 \pm 0.0042$ & $0.0200 \pm 0.0086$ \\
\hline \multicolumn{4}{|l|}{ Aquatic: } \\
\hline Araceae & 0 & $0.0596 \pm 0.0234$ & $0.1044 \pm 0.0260$ \\
\hline Begonia & 0 & $0.0115 \pm 0.0065$ & $0.0197 \pm 0.0070$ \\
\hline Chenopodiaceae & $0.0004 \pm 0.0004$ & $0.0075 \pm 0.0033$ & $0.0075 \pm 0.0032$ \\
\hline Peperomia & $0.0210 \pm 0.0100$ & $0.1216 \pm 0.0285$ & $0.1862 \pm 0.0252$ \\
\hline Typha & $0.0406 \pm 0.0103$ & $0.0362 \pm 0.0148$ & $0.0275 \pm 0.0123$ \\
\hline
\end{tabular}


Table A1.2. Inter-season (rainy season, June-September; dry season, October-May) comparison of pollen composition in pollen rain and feathers from Lake Cuitzeo, Mexico (Mann-Whitney $U$ exact tests $\propto 0.05$ ). Values represent relative frequency of pollen (mean $\pm S E$ ).

\begin{tabular}{|c|c|c|c|c|c|c|c|c|c|}
\hline & \multicolumn{3}{|c|}{ Pollen rain } & \multicolumn{3}{|c|}{ Black-polled Yellowthroat } & \multicolumn{3}{|c|}{ Common Yellowthroat } \\
\hline & Rainy & Dry & P-value & Rainy & Dry & $\mathrm{P}$-value & Rainy & Dry & P-value \\
\hline \multicolumn{10}{|l|}{ Vegetation type: } \\
\hline Secondary & $0.78 \pm 0.01$ & $0.70 \pm 0.01$ & 0.002 & $0.93 \pm 0.02$ & $0.49 \pm 0.06$ & 0.000 & $0.94 \pm 0.01$ & $0.42 \pm 0.04$ & 0.000 \\
\hline Arboreal & $0.16 \pm 0.01$ & $0.24 \pm 0.01$ & 0.001 & $0.06 \pm 0.02$ & $0.14 \pm 0.02$ & 0.059 & $0.05 \pm 0.01$ & $0.14 \pm 0.02$ & 0.019 \\
\hline Aquatic & $0.06 \pm 0.01$ & $0.06 \pm 0.01$ & 0.945 & 0 & $0.37 \pm 0.06$ & 0.000 & 0 & $0.43 \pm 0.05$ & 0.000 \\
\hline \multicolumn{10}{|c|}{ Main $(>5 \%)$ pollen taxa: } \\
\hline Asteraceae & $0.05 \pm 0.01$ & $0.16 \pm 0.01$ & 0.001 & $0.13 \pm 0.04$ & $0.12 \pm 0.03$ & 0.726 & $0.14 \pm 0.03$ & $0.09 \pm 0.02$ & 0.164 \\
\hline Euphorbiaceae & $0.01 \pm 0.00$ & 0 & 0.070 & $0.02 \pm 0.00$ & $0.06 \pm 0.03$ & 0.694 & $0.02 \pm 0.01$ & $0.05 \pm 0.02$ & 0.814 \\
\hline Poaceae & $0.71 \pm 0.02$ & $0.53 \pm 0.02$ & 0.001 & $0.70 \pm 0.06$ & $0.23 \pm 0.06$ & 0.000 & $0.63 \pm 0.02$ & $0.24 \pm 0.04$ & 0.001 \\
\hline Onagraceae & 0 & 0 & 1.000 & $0.07 \pm 0.02$ & $0.01 \pm 0.01$ & 0.006 & $0.14 \pm 0.03$ & $0.01 \pm 0.002$ & 0.000 \\
\hline Araceae & 0 & 0 & 1.000 & 0 & $0.09 \pm 0.03$ & 0.057 & 0 & $0.13 \pm 0.03$ & 0.039 \\
\hline Peperomia & $0.04 \pm 0.01$ & 0 & 0.021 & 0 & $0.19 \pm 0.03$ & 0.000 & 0 & $0.23 \pm 0.02$ & 0.000 \\
\hline Typha & $0.01 \pm 0.01$ & $0.06 \pm 0.01$ & 0.005 & 0 & $0.06 \pm 0.02$ & 0.007 & 0 & $0.03 \pm 0.01$ & 0.146 \\
\hline
\end{tabular}


Table A1.3. Intra-season comparisons between pollen rain (PR) and pollen loads of Black-polled Yellowthroat (BPY) and Common Yellowthroat (CY), using Kruskal-Wallis ANOVA $\left(x_{2}^{2} ; P\right.$-value), and post-hoc Dunn-Bonferroni pairwise tests when applicable ( $z$-test-statistic; $P$-value).

\begin{tabular}{|c|c|c|c|c|c|c|c|c|c|c|c|c|c|c|}
\hline & \multicolumn{7}{|c|}{ Rainy season (June-September) } & \multicolumn{7}{|c|}{ Dry season (October-May) } \\
\hline & \multirow{2}{*}{\multicolumn{2}{|c|}{ Kruskal-Wallis }} & \multicolumn{2}{|c|}{ Dunn-Bonferroni } & \multicolumn{3}{|c|}{ Similitude $\dagger$} & \multirow{2}{*}{\multicolumn{2}{|c|}{ Kruskal-Wallis }} & \multicolumn{2}{|c|}{ Dunn-Bonferroni } & \multicolumn{3}{|c|}{ Similitude $\dagger$} \\
\hline & & & BPY & CY & $\mathrm{PR}$ & $\mathrm{BPY}$ & $\mathrm{CY}$ & & & BPY & $\mathrm{CY}$ & PR & $\mathrm{BPY}$ & $\mathrm{CY}$ \\
\hline Vegetation type: & & & & & & & & & & & & & & \\
\hline Secondary & $12.288 ; 0.002$ & $\begin{array}{l}\text { PR } \\
\text { BPY }\end{array}$ & $-10.625 ; 0.005$ & $\begin{array}{l}-10.357 ; 0.008 \\
0.268 ; 1.000\end{array}$ & A & B & B & $10.383 ; 0.006$ & $\begin{array}{l}\text { PR } \\
\text { BPY }\end{array}$ & $15.786 ; 0.045$ & $\begin{array}{l}19.116 ; 0.004 \\
3.331 ; 1.000\end{array}$ & A & B & B \\
\hline Arboreal & $10.200 ; 0.006$ & $\begin{array}{l}\text { PR } \\
\text { BPY }\end{array}$ & $9.458 ; 0.014$ & $\begin{array}{l}9.690 ; 0.015 \\
0.232 ; 1.000\end{array}$ & A & B & B & $7.792 ; 0.020$ & $\begin{array}{l}\text { PR } \\
\text { BPY }\end{array}$ & $15.750 ; 0.045$ & $\begin{array}{l}16.087 ; 0.020 \\
0.337 ; 1.000\end{array}$ & A & B & B \\
\hline Aquatic & $15.262 ; 0.000$ & $\begin{array}{l}\text { PR } \\
\text { BPY }\end{array}$ & $8.750 ; 0.001$ & $\begin{array}{l}8.750 ; 0.002 \\
0.000 ; 1.000\end{array}$ & A & B & B & $12.818 ; 0.002$ & $\begin{array}{l}\text { PR } \\
\text { BPY }\end{array}$ & $-17.571 ; 0.020$ & $\begin{array}{l}-21.238 ; 0.001 \\
-3.667 ; 1.000\end{array}$ & A & B & B \\
\hline Main taxa $(>5 \%$ o & pollen loads): & & & & & & & & & & & & & \\
\hline Asteraceae & $3.126 ; 0.172$ & & & & A & A & A & $2.927 ; 0.231$ & & & & A & A & A \\
\hline Euphorbiaceae & $0.686 ; 0.710$ & & & & A & A & A & $4.802 ; 0.091$ & & & & A & A & A \\
\hline Poaceae & $4.631 ; 0.099$ & & & & A & A & A & $10.512 ; 0.005$ & $\begin{array}{l}\text { PR } \\
\text { BPY }\end{array}$ & $19.393 ; 0.008$ & $\begin{array}{l}18.008 ; 0.007 \\
-1.385 ; 1.000\end{array}$ & A & B & B \\
\hline Onagraceae & $13.280 ; 0.001$ & $\begin{array}{l}\text { PR } \\
\text { BPY }\end{array}$ & $-7.625 ; 0.061$ & $\begin{array}{l}0.000 ; 0.001 \\
0.139 ; 0.418\end{array}$ & A & $\mathrm{AB}$ & B & $4.527 ; 0.104$ & & & & A & A & A \\
\hline Araceae & $0.000 ; 1.000$ & & & & A & A & A & $5.144 ; 0.076$ & & & & A & A & A \\
\hline Peperomia & $11.602 ; 0.003$ & $\begin{array}{l}\text { PR } \\
\text { BPY }\end{array}$ & $7.000 ; 0.007$ & $\begin{array}{l}7.000 ; 0.009 \\
0.000 ; 1.000\end{array}$ & A & B & B & $14.225 ; 0.001$ & $\begin{array}{l}\text { PR } \\
\text { BPY }\end{array}$ & $-17.250 ; 0.022$ & $\begin{array}{l}-22.167 ; 0.000 \\
-4.917 ; 0.844\end{array}$ & A & B & B \\
\hline Typha & $5.250 ; 0.072$ & & & & A & A & A & $8.788 ; 0.012$ & $\begin{array}{l}\text { PR } \\
\text { BPY }\end{array}$ & $8.714 ; 0.462$ & $\begin{array}{l}15.799 ; 0.014 \\
7.085 ; 0.310\end{array}$ & A & $\mathrm{AB}$ & B \\
\hline
\end{tabular}

$\dagger$ Different letters indicate significant intra-season differences between media (see Table 2 for frequency values). 
Fig. A1.1. Boxplots of pollen rain and pollen loads of Black-polled Yellowthroat (Geothlypis speciosa) and Common Yellowthroat (G. trichas). Y-axis represent relative frequency values; boxes show the inter-quartile range, the bar in the box shows the median and the $\mathrm{x}$ the mean; dots represent outliers. (A), secondary vegetation; (B), arboreal vegetation; (C), aquatic vegetation.

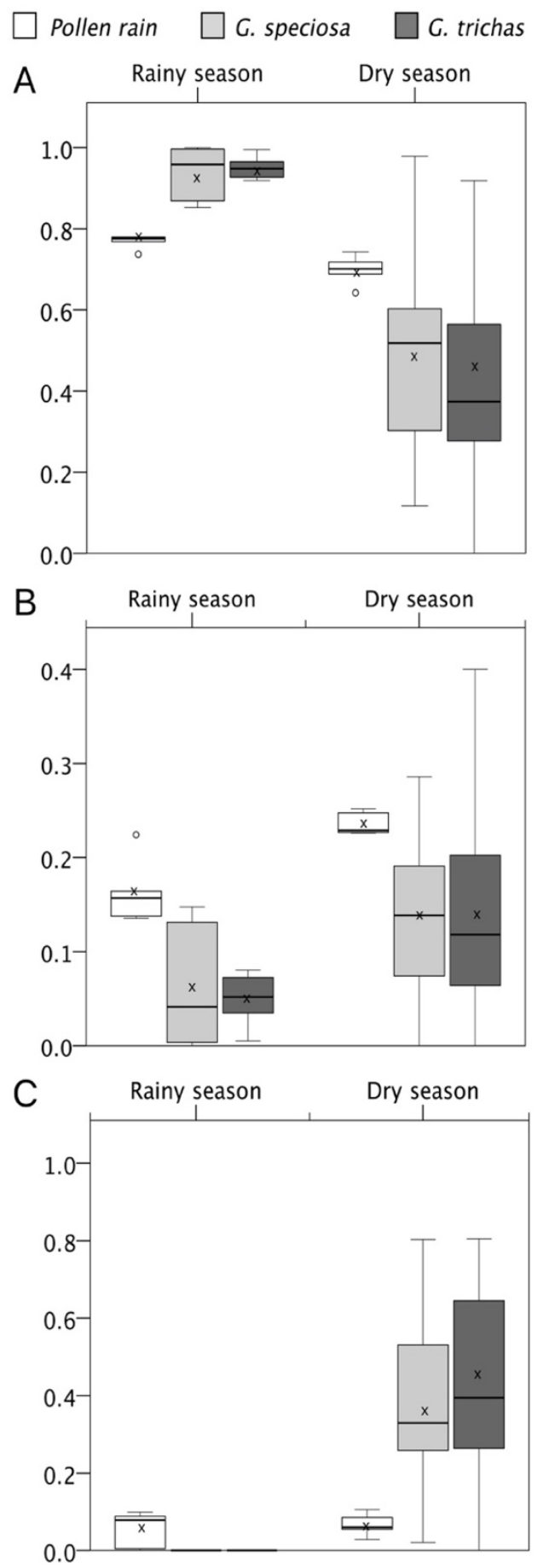


Fig. A1.2. Equitability values (bars represent 95\% CI) of pollen loads (all taxa) in Black-polled Yellowthroat (BPY) and Common Yellowthroat (CY).

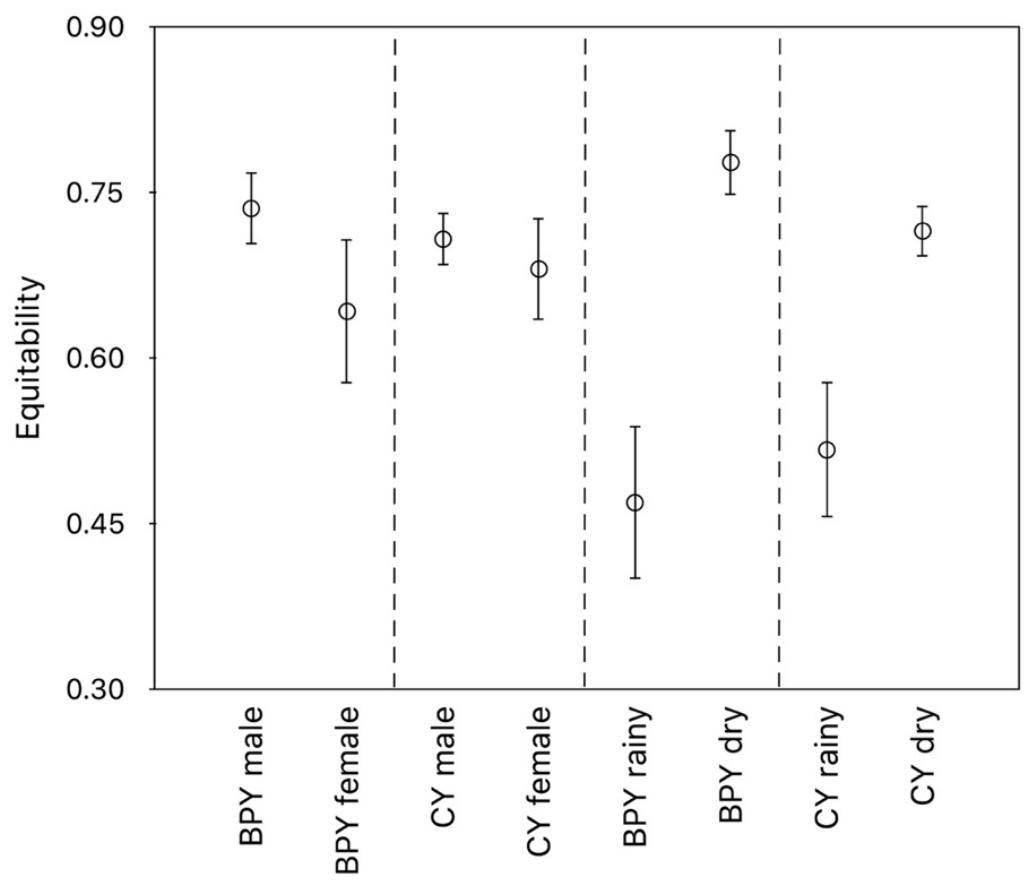

